Volume 6 Issue 2, September 2021:pp. 224 - 235 Copyright @ LamLaj. Faculty of Law, Lambung Mangkurat University, Banjarmasin, South Kalimantan, Indonesia. ISSN: 2502-3136 | e-ISSN: 2502-3128. Open Access at: http://lamlaj.ulm.ac.id/web/

\title{
DYNAMICS OF SHARIA COOPERATIVE REGULATION IN INDONESIA
}

Muhammad Fikri Aufa ${ }^{1}$, Wempy Setyabudi Hernowo ${ }^{2}$, Dewi Nurul Musjtari ${ }^{3}$

Universitas Muhammadiyah Yogyakarta

Jl. Brawijaya, Tamantiro, Kasihan, Kabupaten Bantul, D.I. Yogyakarta, Indonesia m.fikri.psc20@mail.umy.ac.id

Universitas Muhammadiyah Yogyakarta

Jl. Brawijaya, Tamantiro, Kasihan, Kabupaten Bantul, D.I. Yogyakarta, Indonesia Wempy.setyabudi@yahoo.com

Universitas Muhammadiyah Yogyakarta

Jl. Brawijaya, Tamantiro, Kasihan, Kabupaten Bantul, D.I. Yogyakarta, Indonesia dewinurulmusjtari@umy.ac.id

Submitted : 05/06/2021 Reviewed: 04/08/2021 Accepted:13/09/2021

Abstract: The development of Sharia Cooperatives in Indonesia has experienced a significant increase. Islamic cooperatives are one of the alternatives for some members who will build cooperatives based on several sharia principles. The establishment of sharia cooperatives has encountered conflicts, which are not only in Law Number 25 of 1992 on Cooperatives but are also regulated in Law Number 1 of 2013 concerning Micro Financial Institutions. The formulation of the problem of this research is to find legal clarity in the registration and establishment of a sharia cooperative legal body. The research system used in reviewing the registration and establishment of the legal body of Islamic cooperatives uses normative legal research, which is called library research. From the results of this research, the establishment of a sharia cooperative legal body still refers to Law Number 25 of 1992 concerning Cooperatives as replaced by Law Number 11 of 2020 concerning Job Creation. This is because the Microfinance Institution Law only states that the cooperative is a form of MFI legal entity and does not control in detail the cooperative. This system uses statutory provisions as special legal material and is supported by secondary legal materials in the form of books and journal articles.

Keywords: Cooperative Law; Legal Certainty; Microfinance Institution Law;

Sharia Cooperative

DOI: 10.32801/lamlaj.v6i2.261 


\section{INTRODUCTION}

Sharia cooperatives in Indonesia are again in an important increasing trend over the years. This is because the Islamic cooperative is one of the tricks so that the population can increase the work they have, namely by entering as a member of the cooperative. And as a place for residents who have principles in al-Qur'an and as-sunnah, surely the Sharia Cooperative is the greatest alternative that is being sold. Sharia cooperatives, which is nongovernmental groups as people's economic institutions that seek to increase productive businesses and investments based on sharia principles ${ }^{1}$. Sharia cooperatives as one of the foundations in the running of economic activities, especially for middle to lower class citizens. As one of the foundations, Islamic cooperatives have a role in helping citizens and contributing to the running of the national economy ${ }^{2}$.

Sharia cooperatives are also a manifestation of the running of sharia law and economy, which is carrying out their work that has no content and places usury in it. This cooperative is better known as the Sharia Financial Service Cooperative (KJKS) and the Sharia Financial Service Unit (UJKS), and feels the increase in the midst of people's activities that begin

1 Aam Slamet Rusydiana and Abrista Devi, "Mengembangkan Koperasi Syariah Di Indonesia: Pendekatan Interpretative Structural Modelling (ISM)," Economica: Jurnal Ekonomi Islam 9, no. 1 (2018): 2, https://journal.walisongo.ac.id/index.php/ economica/article/view/2181.

2 Maya Apriyana and Sahlan Hasbi, "Preferensi Koperasi Dalam Melakukan Konversi Menjadi Koperasi Syariah: Studi Kasus Pada Koperasi Di Wilayah Bogor," Journal of Islamic Economics and Finance Studies 1, no. 2 (2020): 176, https://ejournal. upnvj.ac.id/index.php/JIEFeS/article/view/2115. to understand the dangers of usury ${ }^{3}$. The existence of a sharia cooperative, so residents can also carry out the structure of Islamic law and carry out the side of the practice of worship because it avoids the economic structure that places usury in it. Riba itself has been regulated and said by Allahin QS Al-Baqarah verse 278:

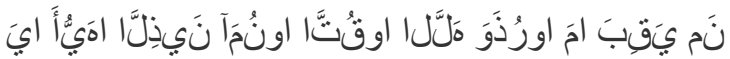

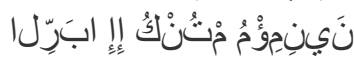

Meaning: "O you who believe! fear Allah and leave the remaining Riba (which has not been collected) if you are a believer. " (Surah AlBaqarah verse 278)

In carrying out the commands that Allah has said, of course, sharia cooperatives are one of the alternatives. The verse instructs Muslims to leave usury in the practice of negotiation, not only in trading but also in jobs in financial institutions ${ }^{4}$. As a sharia financial institution, sharia cooperatives are one of the social institutions of the Islamic law that have started to be popular and developed in Indonesia since the establishment of Sarekat Dagang Islam in $1913{ }^{5}$.

In language, cooperatives come from English, cooperatives, as a combination of 2 syllables co and operation. The term

\footnotetext{
3 Triana Sofiana, "Konstruksi Norma Hukum Koperasi Syariah Dalam Kerangka Sistem Hukum Koperasi Nasional," Jurnal Hukum Islam 12, no. 2 (2014): 140, http://e-journal.iainpekalongan.ac.id/index.php/jhi/ article/view/535.

4 Apriyana and Hasbi, "Preferensi Koperasi Dalam Melakukan Konversi Menjadi Koperasi Syariah: Studi Kasus Pada Koperasi Di Wilayah Bogor.”, 177.

5 Abdullah Safe'i, "Koperasi Syariah: Tinjauan Terhadap Kedudukan Dan Peranannya Dalam Pemberdayaan Ekonomi Kerakyatan," Media Syari'ah : Wahana Kajian Hukum Islam dan Pranata Sosial 14, no. 1 (2012): 42, https://jurnal.ar-raniry. ac.id/index.php/medsyar/article/view/1718.
} 
Cooperative in Dutch is cooperative, which has the meaning of working together which after that the Indonesian people say it through the word cooperative ${ }^{6}$. Meanwhile, Article 1 paragraph 1 of Law Number 25 the Year 1992 related to Cooperatives, states that a cooperative is a business body that contains people or the legal body of a cooperative by eliminating its work based on the basis of all cooperatives as economic movements based on the principle of kinship.

It is stated in the explanation of the cooperative above, if this financial institution is an institution with a legal or legal body position, it means that the establishment and management of a cooperative are considered legally and its authority can be accounted for. The same thing has already been explained that a sharia cooperative is a cooperative that carries out its work based on the basis of sharia. The basis of sharia, which is the Islamic legal decisions based on fatwas or recognition of sharia harmony from the National Sharia Gods of the Indonesian Ulema Council (Decree of the Financial Services Authority Number 14 / POJK.05 / 2014 regarding the Teaching and Monitoring of Micro Financial Institutions).

Other arrangements are also contained in the Regulation of the Minister of Cooperatives and Small and Medium Enterprises Number 02/PER/M.KUKM/II/2017 concerning Amendments to the Regulation of the Minister of Cooperatives and Small and Medium Enterprises Number 15/PER/M.KUKM/ IX/2015 concerning Business Savings and Loans By Cooperatives. The regulation issued by the Ministry of Cooperatives and

\footnotetext{
6 Wahyu Kusuma Dharma, Sofyan Hasan, and Agus Trisaka, "Peran Notaris Dalam Pendirian Koperasi Syariah" (Fakultas Hukum Universitas Sriwijaya, 2021), https://repository.unsri.ac.id/42018/.
}

MSMEs also regulates Savings and Loans Cooperatives. This type of cooperative is included in the category of Microfinance Institutions in the form of cooperative legal entities, one of which is an institution capable of financing SME business activities. KSP has a strategic role for SME developers, but in carrying out its business it has not achieved success as other business entities $\mathrm{do}^{7}$. In the establishment of the KSP, of course, it is still based on the provisions of the applicable laws and regulations by taking into account the feasibility of the business and the benefits for its members. Article 3 paragraph (2) explains that the ratification of the KSP establishment deed is given by issuing 2 (two) documents, namely the legal entity legalization document and the savings and loan business license document.

Behind the setting that has been determined for banking or micro-financial institutions, the sharia cooperative does not have a special legal decision during the establishment and registration process. This matter has meaning if the Islamic cooperative is under the Ministry of Cooperatives, MSMEs, or the Financial Services Authority, and the choice is based on the Cooperative Law or based on the Micro Financial Institution Law. This analysis will also discuss the establishment of a sharia cooperative by reviewing it based on Law Number (No). 11 of 2020 regarding Job Creation and Government Decree Number 7 of 2021 regarding Power, Protection, and Utilization of Cooperatives and Micro, Small, and Medium Efforts. Not just a review through

\footnotetext{
7 Endi Sarwoko, "Analisis Peranan Koperasi Simpan Pinjam / Unit Simpan Pinjam Dalam Upaya Pengembangan UMKM Di Kabupaten Malang," Jurnal Ekonomi Modernisasi 5, no. 3 (2009): 173, https://ejournal.unikama.ac.id/index.php/JEKO/ article/view/227.
} 
the Job Creation Law and PP. 7 of 2021 as a derivative regulation of the Law, This analysis will also discuss in terms of Law Number 1 of 2013 concerning Micro Financial Institutions, and its derivative provisions. Therefore the author in this article will discuss and summarize How Legal Certainty About Registration and Establishment of Sharia Cooperative Legal Entities in Indonesia?

\section{METHOD}

In the presentation and explanation of the problem formulation that has been explained on the introduction side, the writer makes use of the Normative Juridical analysis method. Normative legal analysis is a legal analysis that puts law as an ethical structure building. The meaning of the ethical structure is about principles, ethics, regulations from statutory provisions, judicial decisions, consent, and doctrine (guidance) $^{8}$. This research was conducted using the statute approach.

This method of analysis is what is done based on ongoing statutory provisions and is still the same as the progress of cooperatives in Indonesia. The legal material used by the author in this article is divided into 2 , the first is primary legal material which is arranged based on the analysis in the Hierarchy of Legislation. The use of primary legal materials is also supported by secondary legal materials taken from literature analysis (i.e. taken from books and journals related to the Establishment of Sharia Cooperatives and Microfinance Institutions).

By utilizing normative legal analysis methods in this article, the author will carry out research with qualitative descriptive

\footnotetext{
8 Mukti Fajar Nur Dewata and Yulianto Achmad, Dualisme Penelitian Hukum Normatif \& Empiris, Cetakan I. (Yogyakarta: Pustaka Pelajar, 2010), 34.
}

techniques. The analysis carried out is intended to provide an overview or explanation regarding the legal certainty that exists in the establishment of sharia cooperatives. Not only using qualitative description techniques, but the author also uses a statutory approach and an analytical approach ${ }^{9}$.

\section{ANALYSIS AND DISCUSSION \\ Review of The Establishment and Concept of Sharia Cooperatives in Law Number 25 of 1992 and Law Number 1 of 2013}

It is the same as mentioned in the introduction if cooperatives are the foundation for the running of the country's economic activities and mechanisms, especially for citizens, most of whom are at the middlelower level. The cooperative itself is regulated in Law Number 25 of 1992 concerning Cooperatives. Article 1 paragraph (1) states that a cooperative is a business body with individual members or a cooperative legal body by asserting its activities based on the concept of all cooperatives as a people's economic movement based on the principle of kinship. This understanding states that the people's economic movement is one of the foundations for driving cooperative activity. Cooperatives are separated into 2, namely primary cooperatives and secondary cooperatives. Primary cooperatives are cooperatives that are built by and have individual members,

In short, the primary cooperative is the highest organ, and the secondary cooperative is the side of the primary cooperative. The primary cooperative is not a capital group, but in this cooperative as a group of people with similar economic needs. Secondary cooperatives are usually created for

\footnotetext{
9 Ibid, 35-36.
} 
effectiveness and focus, and the scope of the area is from district, city, province to national ${ }^{10}$. The basis of the 2 forms of cooperatives referred to in the Cooperative Law is the same and as one unit, but the difference is only in the roots and philosophy. In carrying out its financial activities, cooperatives have a concept that is laid out in Article 5, Article 5 paragraph (1), it says if the cooperative carries out the concept of a Cooperative as follows:Membership is voluntary and open;

1. Managementiscarriedoutdemocratically;

2. The distribution of the remaining results of the business is carried out fairly by the number of business services of each member;

3. Providing remuneration which is limited to capital; and

4. Independence.

Not only the concept in application but furthermore in paragraph (2) the concept of enhancing cooperatives which are based on the principles of teaching cooperatives and cooperation between cooperatives are also arranged. The cooperative itself has 4 (four) roles and roles, which are :

1. Build and increase the strength and economic strength of members in particular and citizens usually to improve their economic and social welfare;

2. Take an active role and in an effort to elevate the quality of life for humans and citizens;

3. Strengthen the people's economy as a basis for the capability and resilience of the national economy with cooperatives

\footnotetext{
${ }^{10}$ Nibras Nada Nailufar, "Bentuk Koperasi: Primer Dan Sekunder," Kompas.Com, last modified 2020, accessed April 13, 2021, https:/www.kompas.com/ skola/read/2020/03/24/120000069/bentuk-koperasi-primer-dan-sekunder.
}

as the pillars;

4. Attempt to realize and improve the national economy is called a joint venture based on the principles of kinship and economic democracy.

In establishing a cooperative, of course, there is coordination carried out between individuals who have the same needs. It can be seen as an example of establishing a Barisan Usaha Bersama (KUB) between partners and facilitators if there are residents who do not understand how to set up a cooperative to obtain accompaniment. Usually, the facilitator is a number of service groups who are directly involved in helping the community ${ }^{11}$. The establishment of the cooperative itself in the Cooperative Law is regulated in Chapter IV on the first side regarding development requirements. As the most important organ, primary cooperatives are made up of at least 20 (twenty) people, which has meaning in decisions according to Law no. 25 of 1992 if building a cooperative requires at least 20 people who have similar needs (Article 6 paragraph (1)).

Meanwhile, for secondary cooperatives, further Article 6 paragraph (2) states that if sufficient, only 3 (three) cooperatives can therefore be built. The establishment of the 2 types of cooperatives, certainly gives a story of fundamental inequality, where secondary cooperatives cannot exist if there is no primary cooperative because primary cooperatives are the special side of the whole cooperative. Cooperatives can also be mentioned as one

\footnotetext{
${ }^{11}$ Muhammad Zakiy, Linda Kusumastuti Wardana, and Rhafidilla Vebrynda, "Pendirian Koperasi Kelompok Usaha Bersama (Snack ) Dusun Kasihan RT 6 Tamantirto Kabupaten Bantul D.I. Yogyakarta," Ethos: Jurnal Penelitian dan Pengabdian Masyarakat 8, no. 2 (2020): 147-148, http://dx.doi.org/10.29313/ ethos.v8i2.5333.
} 
of the Micro Financial Institutions (LKM). Article 1 paragraph (1) of Law Number 1 of 2013 concerning Micro Financial Institutions, explains if an MFI is a financial institution specifically built to provide services to improve business and/or empower citizens, either through debt or funding in the micro ratio business to members and citizens. , deposit control,

The basic or juridical principles of cooperatives are not only in the Cooperative Law but as among them and a special source is stated in Article 33 of the 1945 Constitution which is based on information from Sri Edi Swasono "to build a company that is by the people's economy, is a cooperative." ${ }^{12}$. The cooperative itself has 3 basic ideas, generally described as follows : ${ }^{13}$

a. Cooperatives are private organizations voluntarily created by several people who have the same needs to take care of the needs of their members and make mutual profits for cooperative members.

b. Socialist cooperative concept.

c. Developing country concept.

The direction of the establishment of the cooperative is to increase the welfare of the members, in particular, and the citizens usually. In other words, if the cooperative is not only a place for some of its members to move and move the wheels of the national economy, but the cooperative can be for ordinary citizens. To increase and achieve the welfare of members, of course, each person who will build a cooperative must have a similar ideology and direction. One of them is

\footnotetext{
${ }^{12}$ Sri edi Swasono, Ekspose Ekonomika : Mewaspadai Globalisasi Dan Pasar-Bebas (Yogyakarta: Pusat studi Ekonomi Pancasila - UGM, 2010), 50-55.

${ }^{13}$ Sri Edi Swasono, Kebersamaan Dan Asas-Asas Kekeluargaan: Kerakyatan, Nasionalisme, Dan Kemandirian (Jakarta: UNJ Press, 2005), 130.
}

the direction and ideology in the establishment of Sharia Cooperatives. This cooperative is the same as the usual cooperative, but the most striking difference is in the concept and ideological basis of the establishment of this business body.

By the name given, Islamic cooperatives as a business entity that clarify their activities are not only based on the concept of cooperatives but are based on prioritization of Islamic concepts and laws. The presence of sharia cooperatives, even though they have prominent inequalities with cooperatives, are usually inseparable and have a link between one another, this is because sharia cooperatives are one type of cooperative in Indonesia. The existence of a cooperative which is based on and the ideology of Islamic law has existed since 2896 when a civil servant officer of Patih TR. Aria Wiria Atmaja in Purwokerto, Central Java, built a bank for several state employees (Priyayi). The treatment carried out was motivated by a willingness to help several employees who were increasingly suffering because of being entangled by ${ }^{14}$. Sharia cooperatives have operational activities that are similar to other Islamic financial institutions, the area to save funds from members and can be channeled in the form of funding to members who need them ${ }^{15}$. Sharia cooperatives in the study of sharia economic law have 4 (four) concepts in

\footnotetext{
${ }^{14}$ Safe'i, "Koperasi Syariah: Tinjauan Terhadap Kedudukan Dan Peranannya Dalam Pemberdayaan Ekonomi Kerakyatan.”,45-46.

${ }^{15}$ Zaini Abdul Malik, N. Eva Fauziah, and Ifa Hanifia Senjiati, "Pemberdayaan Ibu Rumah Tangga Melalui Literasi Tata Cara Pembentukan Koperasi Syariah Di Desa Babakan Peuteuy Kecamatan Cicalengka," Prosiding SNaPP: Sosial, Ekonomi dan Humaniora 5, no. 1 (2015): 385, http://proceeding.unisba.ac.id/ index.php/sosial/article/view/127.
} 
carrying out its activities, which are : ${ }^{16}$

\section{Mutual Concept}

In carrying out its activities and efforts, Islamic cooperatives have a cooperative principle called kinship and mutual cooperation. The meaning of the kinship principle is that each member of the cooperative is desired to have togetherness and high tolerance for each member, so that it can bring out the bonds and abilities of partners like a family. Meanwhile, the principle of mutual cooperation means that each member is not allowed to have egoism and individualism, so that they are able to create a positive situation and can work together.

\section{Concept of Brotherhood}

It has the meaning of kinship, so that it can create a bond like a womb family and foster a sense of brotherhood for each member. Like a brother, it is therefore forbidden to have exploitative economic practices and the willingness to be mutually dropped between individuals. Although many problems in a cooperative continue to arise, if it is equated with the ability of partners and bonds between members, it will create a strong Islamic cooperative. A simple example of the establishment of a sharia cooperative is because there are 212 cooperatives.

For the first time from the establishment of this cooperative, the masses were mobilized in the 212 Peaceful Action, apart from a diplomatic perspective, the impact that emerged was economically helping some of the masses who followed this comfortable

\footnotetext{
${ }^{16}$ Eka Cahya Wardhani, "Konsep Usaha Bersama Dalam Koperasi Menurut Sri Edi-Swasono Ditinjau Dari Hukum Ekonomi Syari'ah," Jurnal Intelektualita Keislaman, Sosial, dan Sains 7, no. 2 (2018): 202, http://jurnal.radenfatah.ac.id/index.php/ intelektualita/article/view/2903.
}

action and worked together to build a sharia cooperative. ${ }^{17}$

3. Relevation with Indonesian cooperatives tomorrow

Criticism that had once hit gave a meaningful impact to the economy of this country. The impacts include: ${ }^{18}$
a. The decreased purchasing power of citizens;
b. The increasing number of poor families;
c. The increasing number of unemployed;
d. The decrease in citizen confidence in banking; and
e. Increasing several social problems.

A cooperative idea ofeconomic democracy that activities should be included in various sectors of economic activity. Cooperatives have become one of the "pillars of economics" and as a means of democratizing the economic system.

\section{Sharia Economic Law Cooperative}

The social economy mechanism is an economic mechanism that embodies kinship, people's sovereignty, has Pancasila morals, and provides partiality towards the needs of the less strong people. One of them is the special objective of the establishment of the cooperative to improve the welfare of members and general citizens. The cooperative development mechanism and the profit-sharing mechanism can be categorized under syirkah al-uqud.

In its development and decisions, the

\footnotetext{
${ }^{17}$ Yulia Hafizah and Erissa Nilasari, "Gerakan Ekonomi Islam Kontemporer: Studi Terhadap Perkembangan Mitra Koperasi Syariah 212 Di Kalimantan Selatan," At-Taradhi: Jurnal Studi Ekonomi 11, no. 1 (2020): 8, https://jurnal.uin-antasari.ac.id/index.php/taradhi/ article/view/3609.

${ }^{18}$ Wardhani, "Konsep Usaha Bersama Dalam Koperasi Menurut Sri Edi-Swasono Ditinjau Dari Hukum Ekonomi Syari'ah."
} 
Micro Financial Institution Law controls and contains cooperatives. UU no. 1 of 2013 in Article 5 paragraph (1) states that an MFI is established in the form of a legal body, namely a Cooperative or Limited Liability Company (PT). If the law states cooperatives as an option, it means cooperatives according to the Law on Micro Financial Institutions as a form of MFI. Except in the Law on Micro Financial Institutions, Article 7 paragraph (1) stipulates if the construction of a Cooperative is carried out with a deed of establishment that contains the basic budget. Article 8 says if the Basic Budget in establishing a cooperative at least contains:List of founders' names;

a) Name and place of position;

b) Purpose and direction and business sector;

c) Terms regarding membership;

d) Provisions regarding member meetings;

e) Provisions regarding management;

f) Provisions regarding capital;

g) Provisions regarding the period of time his expiry date;

h) Provisions regarding the distribution of the remaining income from the business; and

i) Threat provisions.

Except for the inclusion of the Basic Budget in the establishment deed, it is the same as in the MFI Law if it must be a legal body. However, the Cooperative Law states that if the establishment deed is stipulated by the government (Article 9). Furthermore, in Article 10 paragraphs (1) and (2) if to obtain legitimacy as mentioned in Article 9, several founders who submit wishes are recorded to be accompanied by the establishment of a cooperative, and the legitimacy of the deed of establishment is given within a maximum period of 3 (three) months after receiving the legitimacy wish. . The establishment requirements contained in the Cooperative Law and the Micro Financial Institution Law do not only apply to Conservative Cooperatives, they also apply to the establishment of Sharia Cooperatives.

As a people's economic institution that seeks to increase productivity and investment efforts based on the concept of sharia, the existence of Islamic cooperatives has increased in significance in almost every region in Indonesia. The development of Islamic cooperatives grows on average in terms of assets in a $35 \%-40 \%$ financing to deposit ratio 19. Legitimacy in the establishment of sharia cooperatives is carried out by the Ministry of Law and Human Rights. This has been regulated in the Regulation of the Minister of Law and Human Rights Number 14 of 2019 concerning the Legitimacy of Cooperatives. In the provisions of the Minister of Law and Human Rights, Article 3 paragraph (1) to (3) if the request for the legitimacy of a cooperative establishment certificate is submitted to the minister, in this case, the Minister of Law and Human Rights through the Director General (Dirjen Law and Human Rights). A petitioner who submits a request to the Ministry of Law and Human Rights can be carried out by several founders or the attorney of several founders, but several founders of sharia cooperatives can only give the power to a notary who has been jointly elected.

Establishment, Registration and Changes in Rules regarding Sharia Cooperatives in Law Number 11 of 2020 concerning Job Creation

\footnotetext{
${ }^{19}$ Rusydiana and Devi, "Mengembangkan Koperasi Syariah Di Indonesia: Pendekatan Interpretative Structural Modelling (ISM).”
} 
The establishment of cooperatives is currently undergoing changes with the passing of Law Number 11 of 2020 concerning Job Creation. In contrast to the Cooperative Law, in the Job Creation Law, the establishment of primary cooperatives in Article 6 paragraph (1) is made by at least 9 (nine) people. This means that if there is a simplification in the establishment of primary cooperatives, which originally had at least 20 (twenty) people, with the passing of the law there were at least 9 (nine) people. This has also been clarified in Government Regulation Number 7 of 2021 concerning Relief, Protection, and Utilization of Cooperatives and Micro, Small and Medium Enterprises. Article 4 PP No 7 Tahun 2021.

The arrangement for the establishment of cooperatives which are regulated in the Job Creation Law and PP on the Relief, Protection and Utilization of Cooperatives and Micro, Small and Medium Enterprises applies in the establishment of sharia cooperatives. In the decision not only based on the positive law that runs, but several approaches can also be applied, the first is a formal or material Islamic approach. Literally, Islamic law already exists in the arrangement of sharia cooperatives in the Job Creation Law and PP No. 7 of 2021, which was when before the arrangement of the Islamic cooperative in the Cooperative Law was not mentioned in detail. The second is the material approach to legal content, in which Islamic law in the taqnin process is realized as several sources of positive legal content, where the principles and concepts live up to each product of the provisions of the legislation ${ }^{20}$.

\footnotetext{
${ }^{20}$ Sofiana, "Konstruksi Norma Hukum Koperasi Syariah Dalam Kerangka Sistem Hukum Koperasi Nasional."
}

The establishment of sharia cooperatives as a form of the legal body for non-bank financial institutions, experiences dualism in its regulation. In textual terms, the Micro Financial Institution Law stipulates the requirements for an establishment with 2 (two) legal forms, which is a Cooperative or a Limited Liability Company. But it is important to remember if it is not only sharia cooperatives and MFIs that specifically run financial businesses, it is divided into Savings and Loans Cooperatives (KSP), Deposit and Loans Units (USP), Sharia Financial Services Cooperatives (KJKS), and Sharia Financial Services Units (UJKS).(Muhtarom, 2016). In general, cooperatives that are regulated in the Cooperative Law, whether conservative or sharia, are monitored by the Ministry of Cooperatives and MSMEs. But in the Micro Financial Institution Law, a cooperative classified as a Micro Financial Institution is the activity of the cooperative to run a service business to increase business and empower citizens either through debt or funding in the micro ratio business to members and residents, managing savings, or providing business improvement discussion services. (Article 11 paragraph (1)).

Sharia cooperative activities that exist under Law 1/2013 are monitored by the Financial Services Authority. In Article 2 paragraph (1) the Financial Services Authority carries out Guidance, structuring, and monitoring of MFIs by OJK. The monitoring carried out by the OJK cannot be separated from the arrangement with the Ministry of Cooperatives and MSMEs. The establishment of a Sharia Cooperative must bring in a Sharia Supervisory Board in its body. Article 21 paragraph (1) states that the sharia cooperative foundation to be established consists of a 
Meeting of Members, Management, and Supervisors. Furthermore, it is also added in paragraph (2) that Sharia Cooperatives are required to have a Sharia Supervisory Board. As one of the conditions contained in the Article, therefore the Sharia Supervisory Board is chosen to monitor the activities carried out by the sharia cooperative. SSB is divided into 1 (one) person or more, which of course must have a discourse and knowledge about the concept of sharia and the SSB is appointed by the Members Meeting.

The number of rules that conflict with each other, of course, the establishment of Sharia Cooperatives remains focused on the Cooperative Law which has been amended by the Job Creation Law along with its derivative rules. The establishment of sharia cooperatives as mentioned in the omnibus law, can be established by a minimum of 9 people. This rule still applies to Microfinance Institutions in the form of cooperatives. The deed of establishment of the cooperative must obtain approval from the Ministry of Law and Human Rights in order to obtain legal entity status. It is explained in Article 3 paragraph (1) of the Regulation of the Minister of Law and Human Rights Number 14 of 2019 concerning Ratification of Cooperatives, that the application for ratification of the deed of establishment of cooperatives is submitted by the Petitioner to the Minister through the Director General, the applicant in this case further in paragraph (2) can carried out by the founders of sharia cooperatives or the proxies of the founders, and submitted through the Legal Entity Administration System (paragraph (3)). Not only in the process of ratifying the deed of establishment, the name of the sharia cooperative needs to be submitted for the name of the cooperative as regulated in Article 5.

Furthermore, in the Regulation of the Minister of Cooperatives and Small and Medium Enterprises Number 9 of 2018 concerning the Implementation and Development of Cooperatives, cooperatives that havereceivedapproval from the Ministry of Law and Human Rights of sharia cooperatives are registered with the SISMINBHKOP of the Ministry of Cooperatives and MSMEs, the names and types of Sharia Cooperatives will be determined at the establishment meeting ( Savings and Loans Cooperative or a Sharia Financing and Savings Cooperative). Also, the Sharia Supervisory Board of the Cooperative has received a recommendation from the Indonesian Ulama Council in the area of establishment of the National Sharia Council - the Indonesian Ulama Council or the Sharia Supervisory Board Education and Training Certificate from DSN-MUI.

\section{CONCLUSION}

From the description that has been done in the discussion section, it can be concluded that the establishment of a sharia cooperative has now been regulated in Law Number 11 of 2020 concerning Job Creation or Omnibus Law which was originally laid out in Law Number 25 of 1992 concerning Cooperatives, which in its decision the Sharia Cooperative called the Primary Cooperative was built by at least 9 (nine) the previous person after at least 20 (twenty) people, and this is clarified in the derivative provisions, namely Government Regulation Number 7 of 2021. The establishment and registration of a Sharia Cooperative are carried out by submitting a request for a legal entity to the Ministry of Law and Human Rights. The submission of the deed of establishment of this sharia cooperative 
has been regulated in the Regulation of the Minister of Law and Human Rights Number 14 of 2019 concerning the Ratification of Cooperatives. Sharia cooperatives are built on the basis of laws that control cooperatives, although the Microfinance Institution Law controls cooperatives as a form of MFI. But the decision is still based on the Cooperative Law which has been replaced by the Job Creation Law and is under the supervision of the Ministry of Cooperatives and MSMEs.

\section{BIBLIOGRAPHY}

\section{Books}

Dewata, Mukti Fajar Nur, and Yulianto Achmad. Dualisme Penelitian Hukum Normatif \& Empiris. Cetakan I. Yogyakarta: Pustaka Pelajar, 2010.

Swasono, Sri edi. Ekspose Ekonomika: Mewaspadai Globalisasi Dan PasarBebas. Yogyakarta: Pusat studi Ekonomi Pancasila - UGM, 2010.

Swasono, Sri Edi. Kebersamaan Dan Asas-Asas Kekeluargaan: Kerakyatan, Nasionalisme, Dan Kemandirian. Jakarta: UNJ Press, 2005.

\section{Journal}

Apriyana, Maya, and Sahlan Hasbi. "Preferensi Koperasi Dalam Melakukan Konversi Menjadi Koperasi Syariah: Studi Kasus Pada Koperasi Di Wilayah Bogor." Journal of Islamic Economics and Finance Studies 1, no. 2 (2020): 176. https:// ejournal.upnvj.ac.id/index.php/JIEFeS/ article/view/2115.

Hafizah, Yulia, and Erissa Nilasari. "Gerakan Ekonomi Islam Kontemporer: Studi Terhadap Perkembangan Mitra Koperasi Syariah 212 Di Kalimantan Selatan." AtTaradhi: Jurnal Studi Ekonomi 11, no. 1 (2020): 8. https://jurnal.uin-antasari.ac.id/ index.php/taradhi/article/view/3609.

Malik, Zaini Abdul, N. Eva Fauziah, and Ifa Hanifia Senjiati. "Pemberdayaan Ibu Rumah Tangga Melalui Literasi Tata Cara Pembentukan Koperasi Syariah Di Desa Babakan Peuteuy Kecamatan Cicalengka." Prosiding SNaPP: Sosial, Ekonomi dan Humaniora 5, no. 1 (2015): 385. http:// proceeding.unisba.ac.id/index.php/sosial/ article/view/127.

Rusydiana, Aam Slamet, and Abrista Devi. "Mengembangkan Koperasi Syariah Di Indonesia: Pendekatan Interpretative Structural Modelling (ISM)." Economica: Jurnal Ekonomi Islam 9, no. 1 (2018): 2. https://journal.walisongo.ac.id/index.php/ economica/article/view/2181.

Safe'i, Abdullah. "Koperasi Syariah: Tinjauan Terhadap Kedudukan Dan Peranannya Dalam Pemberdayaan Ekonomi Kerakyatan." Media Syari'ah : Wahana Kajian Hukum Islam dan Pranata Sosial 14, no. 1 (2012): 42. https://jurnal. ar-raniry.ac.id/index.php/medsyar/article/ view/1718.

Sarwoko, Endi. “Analisis Peranan Koperasi Simpan Pinjam / Unit Simpan Pinjam Dalam Upaya Pengembangan UMKM Di Kabupaten Malang." Jurnal Ekonomi Modernisasi 5, no. 3 (2009): 173. https:// ejournal.unikama.ac.id/index.php/JEKO/ article/view/227.

Sofiana, Triana. "Konstruksi Norma Hukum Koperasi Syariah Dalam Kerangka Sistem Hukum Koperasi Nasional." Jurnal Hukum Islam 12, no. 2 (2014): 140. http:// e-journal.iainpekalongan.ac.id/index.php/ jhi/article/view/535.

Wardhani, Eka Cahya. "Konsep Usaha Bersama Dalam Koperasi Menurut Sri Edi-Swasono Ditinjau Dari Hukum 
Ekonomi Syari'ah.” Jurnal Intelektualita Keislaman, Sosial, dan Sains 7, no. 2 (2018): 202. http://jurnal.radenfatah.ac.id/ index.php/intelektualita/article/view/2903. Zakiy, Muhammad, Linda Kusumastuti Wardana, and Rhafidilla Vebrynda. "Pendirian Koperasi Kelompok Usaha Bersama (Snack ) Dusun Kasihan RT 6 Tamantirto Kabupaten Bantul D.I. Yogyakarta." Ethos: Jurnal Penelitian dan Pengabdian Masyarakat 8, no. 2 (2020): 147-148. http://dx.doi.org/10.29313/ ethos.v8i2.5333.

\section{Internet}

Nailufar, Nibras Nada. "Bentuk Koperasi: Primer Dan Sekunder." Kompas.Com. Last modified 2020. Accessed April 13, 2021. https://www.kompas.com/skola/ $\mathrm{read} / 2020 / 03 / 24 / 120000069 /$ bentukkoperasi--primer-dan-sekunder.

\section{Thesis}

Dharma, Wahyu Kusuma, Sofyan Hasan, and Agus Trisaka. "Peran Notaris Dalam Pendirian Koperasi Syariah." Fakultas Hukum Universitas Sriwijaya, 2021. https://repository.unsri.ac.id/42018/.

\section{Law and Regulation}

Government Regulation Number 7 of 2021 concerning Relief, Protection, and Utilization of Cooperatives and Micro, Small and Medium Enterprises
Law Number 25 of 1992 concerning Cooperatives

Law Number 1 of 2013 concerning Micro Financial Institutions

Law Number 11 of 2020 concerning Job Creation

Regulation of the Minister of Cooperatives and Small and Medium Enterprises Number 02/PER/M.KUKM/II/2017 concerning Amendments to the Regulation of the Minister of Cooperatives and Small and Medium Enterprises Number 15/PER/M. KUKM/IX/2015 concerning Business Savings and Loans By Cooperatives

Regulation of the Minister of Cooperatives and Small and Medium Enterprises Number 9 of 2018 concerning the Implementation and Development of Cooperatives, cooperatives

Regulation of the Minister of Law and Human Rights Number 14 of 2019 concerning the Legitimacy of Cooperatives 